Article

\title{
Synergistic Removal of Static and Dynamic Staphylococcus aureus Biofilms by Combined Treatment with a Bacteriophage Endolysin and a Polysaccharide Depolymerase
}

\author{
Nanna M. C. Olsen ${ }^{1,2}$, Elowine Thiran ${ }^{1,3}$, Tobias Hasler ${ }^{1}$, Thomas Vanzieleghem ${ }^{3}$, \\ Georgios N. Belibasakis ${ }^{4,5}{ }^{\circledR}$, Jacques Mahillon ${ }^{3}$, Martin J. Loessner ${ }^{1}$ and \\ Mathias Schmelcher ${ }^{1, *}$ (iD \\ 1 Institute of Food, Nutrition and Health, ETH Zurich, Schmelzbergstrasse 7, 8092 Zurich, Switzerland; \\ nanna.olsen@bio.ku.dk (N.M.C.O.); elowine.thiran@gmail.com (E.T.); tobias.hasler@uzh.ch (T.H.); \\ martin.loessner@ethz.ch (M.J.L.) \\ 2 Section of Microbiology, Department of Biology, University of Copenhagen, Universitetsparken 15, \\ 2100 Copenhagen $\varnothing$, Denmark \\ 3 Earth and Life Institute, Université Catholique de Louvain, Croix du Sud 2/L7.05.12, 1348 \\ Louvain-la-Neuve, Belgium; t.vanzieleghem@onelife-bf.com (T.V.); jacques.mahillon@uclouvain.be (J.M.) \\ 4 Division of Oral Diseases, Department of Dental Medicine, Karolinska Institutet, Alfred Nobels Allé 8, \\ 14104 Huddinge, Sweden; george.belibasakis@ki.se \\ 5 Institute of Oral Biology, Center of Dental Medicine, University of Zurich, Plattenstrasse 11, \\ 8032 Zurich, Switzerland \\ * Correspondence: mathias.schmelcher@hest.ethz.ch
}

Received: 22 June 2018; Accepted: 17 August 2018; Published: 18 August 2018

\begin{abstract}
Staphylococcus aureus is an important pathogen and biofilm former. Biofilms cause problems in clinics and food production and are highly recalcitrant to antibiotics and sanitizers. Bacteriophage endolysins kill bacteria by degrading their cell wall and are therefore deemed promising antimicrobials and anti-biofilm agents. Depolymerases targeting polysaccharides in the extracellular matrix have been suggested as parts of a multi-enzyme approach to eradicate biofilms. The efficacy of endolysins and depolymerases against $S$. aureus biofilms in static models has been demonstrated. However, there is a lack of studies evaluating their activity against biofilms grown under more realistic conditions. Here, we investigated the efficacy of the endolysin LysK and the poly- $N$-acetylglucosamine depolymerase DA7 against staphylococcal biofilms in static and dynamic (flow cell-based) models. LysK showed activity against multiple S. aureus strains, and both LysK and DA7 removed static and dynamic biofilms from polystyrene and glass surfaces at low micromolar and nanomolar concentrations, respectively. When combined, the enzymes acted synergistically, as demonstrated by crystal violet staining of static biofilms, significantly reducing viable cell counts compared to individual enzyme treatment in the dynamic model, and confocal laser scanning microscopy. Overall, our results suggest that LysK and DA7 are potent anti-biofilm agents, alone and in combination.
\end{abstract}

Keywords: endolysin; depolymerase; biofilm; S. aureus; synergy; antimicrobial; dynamic model; flow cell

\section{Introduction}

Staphylococcus aureus is an opportunistic bacterial pathogen which can cause a broad variety of infectious diseases in both humans and animals. The long list of medical conditions caused 
by these Gram-positive bacteria includes abscesses of skin, muscles and various organs, infective endocarditis, osteomyelitis, pneumonia, and toxic shock syndrome [1,2]. S. aureus can also exist in polymicrobial biofilms of the oral cavity [3] and has frequently been implicated in oral infections, such as peri-implantitis [4,5]. In addition, $S$. aureus is frequently responsible for food poisoning via production of heat-stable enterotoxins [6]. Besides their important role as human pathogens, staphylococci (and S. aureus in particular) are a major cause of bovine mastitis, an infection of the mammary gland in cows. This leads to severe losses in milk production and quality and increased costs due to veterinary treatment and culling of animals, making it the most costly disease for the dairy industry [7]. In both human and veterinary clinics, the increasing prevalence of antibiotic-resistant strains such as methicillin-resistant $S$. aureus (MRSA) as well as the ability of staphylococci to form biofilms result in prolonged therapies and increased treatment costs [8,9].

Biofilms are sessile communities of bacteria embedded in a self-produced extracellular matrix that can grow attached to biotic and abiotic surfaces and as free-floating pellicle structures. The extracellular biofilm matrix consists of multiple components, including extracellular DNA, proteins, environmental components and exopolysaccharides, which provide structure and resilience and often constitute the major part of the matrix $[10,11]$. One exopolysaccharide frequently found in staphylococcal biofilms is poly-N-acetylglucosamine (PNAG), also referred to as polysaccharide intercellular adhesin (PIA), which is produced by enzymes encoded within the icaADBC operon [9]. The ability to form biofilms represents an important virulence factor for many pathogenic bacteria, including staphylococci, and is associated with an increased tolerance to antimicrobial agents and host defenses [12]. In addition, in the food industry, biofilms on food processing surfaces cause major problems. Due to their high levels of recalcitrance towards sanitizers and cleaning processes, they constitute permanent sources of contamination [13]. In S. aureus-induced bovine mastitis, the formation of biofilms is believed to contribute to bacterial persistence in the udder, the recurrence of intramammary infections, and the difficulty to treat these infections [14].

Endolysins are bacteriophage-encoded peptidoglycan hydrolases with the function to lyse the bacterial host cell by degrading its cell wall at the end of the lytic multiplication cycle of the phage. In their natural context, endolysins gain access to their peptidoglycan substrate from within the bacterial cell by help of cytoplasmic membrane-perforating holin proteins [15]. However, in the absence of an outer membrane in Gram-positive bacteria, these enzymes can also access the peptidoglycan and destroy the bacterial target cell from the outside, which renders them promising antibacterial agents [16-18]. Their major advantages as antimicrobials include their rapid killing activity against antibiotic-sensitive and -resistant strains, their specificity for their target bacteria, and their low chance of resistance development. Numerous in vitro studies and animal models of bacterial infection have demonstrated their efficacy as antimicrobial agents against multiple pathogens [19,20]. A recent study compared the efficacies of nine unique peptidoglycan hydrolases including eight phage endolysins and one bacteriocin against $S$. aureus, using multiple in vitro activity assays, a mouse model of systemic MRSA infection, and a static biofilm reduction assay [21]. The most potent endolysin within this set of enzymes, LysK [22], demonstrated high staphylolytic activity against all tested strains (including MRSA strains and other clinical isolates), protected $100 \%$ of MRSA-infected mice from death, and was the most effective endolysin at degrading S. aureus biofilms in the 96-well plate-based model [21].

Similar static biofilm models have also been employed to investigate the ability of other endolysins [21,23-25] as well as various enzymes attacking the extracellular matrix to degrade staphylococcal biofilms. The latter include DNase I, which can degrade extracellular DNA [26], the Aggregatibacter actinomycetemcomitans-derived PNAG depolymerase dispersin B [27,28], and the phage-derived exopolysaccharide depolymerase Dpo7 [29]. The combined application of such enzymes that simultaneously target multiple components of a biofilm, thereby potentially capitalizing on synergistic effects, has been suggested as a promising approach to prevent biofilm formation and to eradicate mature biofilms [10]. While the static biofilm models used in the aforementioned studies may provide first insights into the anti-biofilm activities of such agents, they insufficiently mimic natural 
conditions encountered in the human body or the food industry, where growing biofilms are often exposed to shear forces under the continuous flow of liquids. Therefore, including more sophisticated dynamic models such as flow-cell systems is desirable in studies evaluating the efficacy of anti-biofilm agents $[23,30,31]$.

Here, we further investigate the activity of the endolysin LysK against S. aureus biofilms, employing both conventional static and flow-cell-based dynamic models. Moreover, we evaluate the anti-biofilm efficacy of enzymes targeting the extracellular matrix, including a PNAG depolymerase with homology to dispersin B, alone and in combination with LysK.

\section{Materials and Methods}

\subsection{Bacterial Strains, Plasmids, and Culture Conditions}

Escherichia coli strains XL1-Blue MRF' and BL21-Gold(DE3) (Agilent Technologies, Santa Clara, CA, USA) were used for cloning of $A$. actinomycetemcomitans-derived genes encoding different depolymerase enzymes and expression of recombinant proteins. BL21-Gold(DE3) harboring a plasmid construct coding for the $S$. aureus phage endolysin LysK in a pET-21a backbone (EMD Biosciences, San Diego, CA, USA) served as expression strain for recombinant production of a C-terminally $6 \times$ His-tagged version of LysK [21]. E. coli strains were cultured at $37^{\circ} \mathrm{C}$ in Luria-Bertani (LB) medium supplemented with ampicillin $(100 \mu \mathrm{g} / \mathrm{mL}$; for BL21-Gold(DE3)) or ampicillin and tetracycline (30 $\mu \mathrm{g} / \mathrm{mL}$; for XL1-Blue MRF') for plasmid selection. S. aureus and A. actinomycetemcomitans strains used in this work are listed in Table 1. S. aureus was routinely cultured aerobically in tryptic soy broth (TSB; Biolife, Milan, Italy) at $37^{\circ} \mathrm{C}$, and A. actinomycetemcomitans was grown on Difco ${ }^{\mathrm{TM}} \mathrm{Columbia}$ Blood Agar plates (BD, Allschwil, Switzerland) at $37{ }^{\circ} \mathrm{C}$ in the presence of $10 \% \mathrm{CO}_{2}$.

Table 1. Bacterial strains used in this work.

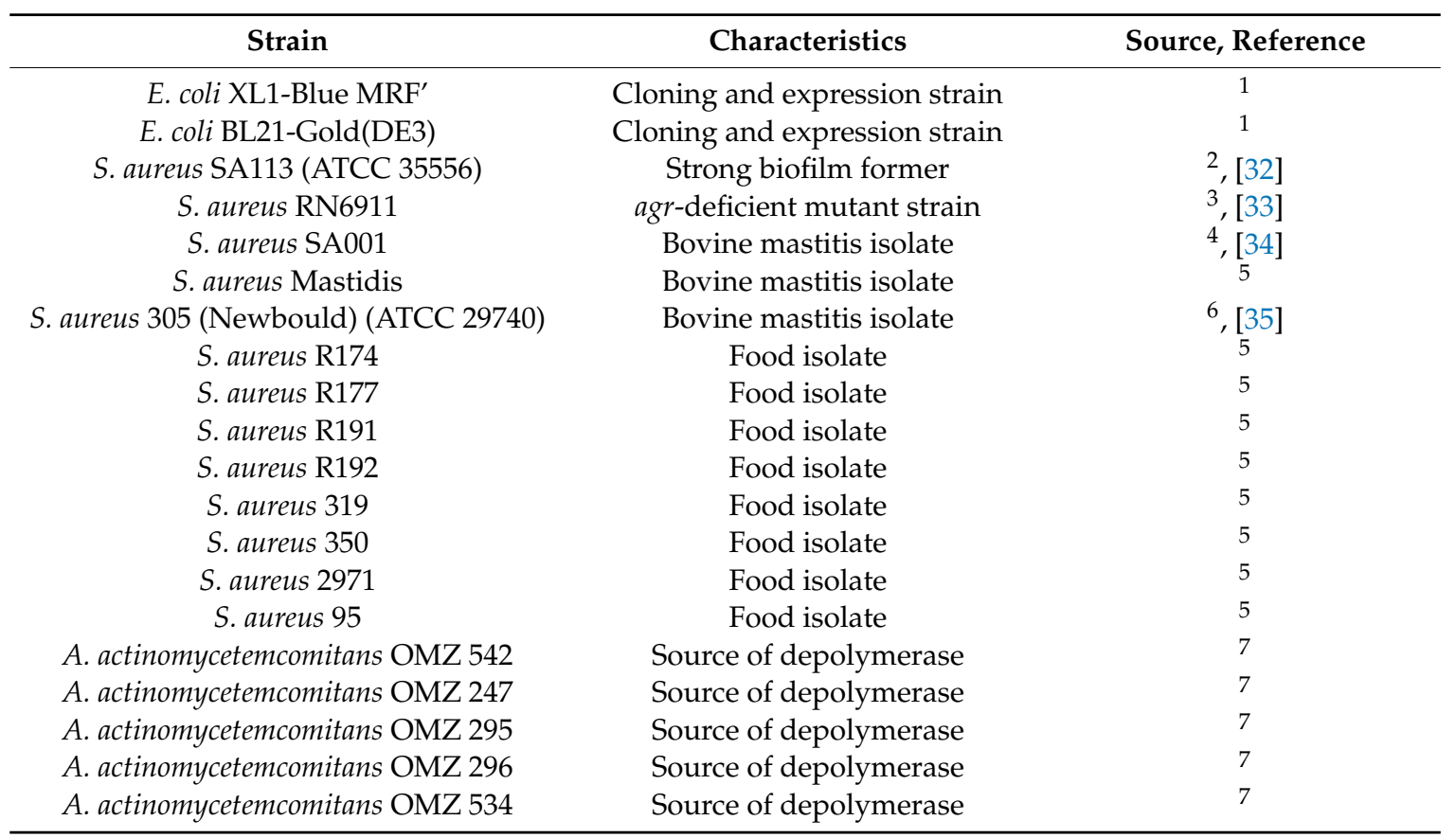

${ }^{1}$ Agilent Technologies, Santa Clara, CA, USA; ${ }^{2}$ Andreas Peschel, University of Tübingen, Tübingen, Germany;

${ }^{3}$ Brigitte Berger-Bächi, University of Zurich, Zurich, Switzerland; ${ }^{4}$ Yasunori Tanji, Tokyo Institute of Technology, Yokohama, Japan; ${ }^{5}$ Roger Stephan, University of Zurich, Zurich, Switzerland; ${ }^{6}$ David M. Donovan, ARS, USDA, Beltsville, MD, USA; ${ }^{7}$ Georgios Belibasakis, Karolinska Institutet, Stockholm, Sweden (formerly at University of Zurich, Zurich, Switzerland). 


\subsection{DNA Techniques and Cloning Procedures}

Standard molecular biology techniques [36] were used for cloning of recombinant A. actinomycetemcomitans-derived depolymerase constructs. Colony material from 5 different A. actinomycetemcomitans strains (Table 1) served as templates for PCR amplification of respective genes using Phusion ${ }^{\circledR}$ High-Fidelity DNA Polymerase (New England Biolabs, Allschwil, Switzerland). Primers were designed based on the nucleotide sequence of the previously described A. actinomycetemcomitans-derived DspB depolymerase [27]. Primer pair DA_BamHI_F (TGCAGGATCCAATTGTTGCGTAAAAGGC) and DA_SalI_R (ACTTGTCGACTTACTCATCCCC ATTCGTC) was used for generation of N-terminally $6 \times$ His-tagged constructs, and primer pair DA_NdeI_F (AGTCTGTTCACATATGAATTGTTGCGTAAAAGGC) and DA_XhoI_R (CTGATACT CGAGCTCATCCCCATTCGTC) for generation of C-terminally $6 \times$ His-tagged proteins. Resulting fragments were inserted into BamHI and SalI or NdeI and XhoI restriction sites of the plasmids pQE-30 (Qiagen, Hilden, Germany) or pET-21a (EMD Biosciences, San Diego, CA, USA), encoding N- or C-terminal His-tags, respectively. The plasmid constructs were introduced into E. coli XL1-Blue MRF' (for pQE-30-based constructs) or E. coli BL21-Gold(DE3) (for pET-21a-based constructs). All sequences were verified by nucleotide sequencing (GATC, Konstanz, Germany).

\subsection{Protein Expression and Purification}

Expression of $6 \times$ His-tagged proteins in E. coli and purification via immobilized metal ion affinity chromatography was performed essentially as previously described [37]. In brief, bacterial cultures were grown in LB medium optimized for protein expression (LB-PE) [38] supplemented with antibiotics for plasmid selection at $37^{\circ} \mathrm{C}$. Once an $\mathrm{OD}_{600 \mathrm{~nm}}$ of 0.5 was reached, cultures were cooled down on ice, and protein expression was induced by addition of $0.5 \mathrm{mM}$ IPTG. Following incubation at $19^{\circ} \mathrm{C}$ for $18 \mathrm{~h}$, bacterial cells were harvested by centrifugation and resuspended in buffer A (50 mM NaH $2 \mathrm{PO}_{4}, 500 \mathrm{mM} \mathrm{NaCl}, 5 \mathrm{mM}$ imidazole, $0.1 \%$ Tween 20, pH 8; for depolymerases) or lysis buffer (50 mM NaH $\mathrm{PO}_{4}, 300 \mathrm{mM} \mathrm{NaCl}, 10 \mathrm{mM}$ imidazole, 30\% glycerol, pH 8; for LysK). Cells were disrupted using a Stansted pressure cell homogenizer (SPCH-10-230V; Stansted Fluid Power, Harlow, UK). Lysates were cleared by centrifugation, and target proteins purified from the crude extracts by immobilized metal ion affinity chromatography using low-density nickel resin (ABT, Madrid, Spain) in Econo-Pac gravity flow columns (Bio-Rad, Cressier, Switzerland). Proteins were eluted with buffer $\mathrm{B}\left(50 \mathrm{mM} \mathrm{NaH}{ }_{2} \mathrm{PO}_{4}, 500 \mathrm{mM} \mathrm{NaCl}, 250 \mathrm{mM}\right.$ imidazole, $0.1 \%$ Tween 20, $\mathrm{pH}$ 8; for depolymerases) or elution buffer (50 $\mathrm{mM} \mathrm{NaH}_{2} \mathrm{PO}_{4}, 300 \mathrm{mM} \mathrm{NaCl}, 250 \mathrm{mM}$ imidazole, $30 \%$ glycerol, pH 8; for LysK). Eluted fractions with high protein concentration were pooled, dialyzed against dialysis buffer $(50 \mathrm{mM}$ $\mathrm{NaH}_{2} \mathrm{PO}_{4}, 100 \mathrm{mM} \mathrm{NaCl}, 0.005 \%$ Tween 20, pH 8 for depolymerases; $50 \mathrm{mM} \mathrm{NaH}_{2} \mathrm{PO}_{4}, 300 \mathrm{mM} \mathrm{NaCl}$, $30 \%$ glycerol, $\mathrm{pH} 8$ for LysK) and filter-sterilized $(0.2 \mu \mathrm{M})$. Protein identity and purity were assessed by sodium dodecyl sulfate polyacrylamide gel electrophoresis (SDS-PAGE), protein concentrations were measured spectrophotometrically (NanoDrop ND-100, NanoDrop Technologies, Wilmington, DE, USA), and protein preparations were stored on ice.

\subsection{Static Biofilm Model}

Static biofilm reduction assays were conducted as previously described [21] to test the efficacy of LysK, A. actinomycetemcomitans-derived polysaccharide depolymerases, and DNase I (Sigma-Aldrich, Buchs, Switzerland) against $S$. aureus biofilms. In brief, biofilms were grown in TSB supplemented with $0.25 \% \mathrm{D}(+)$-glucose (TSBG) in a polystyrene 96-well plate for $24 \mathrm{~h}$ at $30^{\circ} \mathrm{C}$. The biofilms were washed with phosphate-buffered saline (PBS) and treated with serial dilutions of LysK for $2.5 \mathrm{~h}$ at $37^{\circ} \mathrm{C}$ (standard protocol). In the case of the depolymerases and DNase I, the standard protocol was modified and treatment was done for $30 \mathrm{~min}$ at $30^{\circ} \mathrm{C}$ and for $1 \mathrm{~h}$ at $37^{\circ} \mathrm{C}$, respectively. For synergy experiments with LysK and the depolymerase DA7, biofilms were treated for $1 \mathrm{~h}$ at $37^{\circ} \mathrm{C}$, representing a compromise between the two conditions used for the individual enzyme treatments. After treatment, 
residual biofilms were washed with PBS, stained with $0.4 \%$ crystal violet $(\mathrm{CV})$, and washed again. The CV stain was dissolved in $96 \%$ ethanol, and the absorption at $595 \mathrm{~nm}\left(\mathrm{~A}_{595 \mathrm{~nm}}\right)$ of the resulting solutions was measured spectrophotometrically.

\subsection{Dynamic Biofilm Model}

For studying the efficacy of LysK and DA7 to eradicate dynamically grown S. aureus biofilms, a Biostream flow cell system [31,39] was employed. The flow cell consists of a molded silicone block forming a flow chamber, which is sealed on the bottom side with a glass slide (Gerhard Menzel GmbH, Braunschweig, Germany) serving as the surface for biofilm growth. Glass slides were pretreated with a mix (2:1) of $98 \%$ sulfuric acid and 30\% hydrogen peroxide to remove organic and inorganic material and thoroughly washed with deionized water. The entire assembly, consisting of the flow cell, silicon tubes (1.6 mm inner diameter) connected by straight and Y-shaped Kynar connectors (Fisher Scientific, Reinach, Switzerland), and Schott Duran glass bottles equipped with two- and three-port screw caps and pressure equalization sets (VWR, Dietikon, Switzerland) was autoclaved before use. To ensure a continuous flow of medium during biofilm growth, the assembly was connected to a Minipuls Evolution peristaltic pump (Gilson, Middleton, WI, USA). To initiate biofilm growth, $20 \mathrm{~mL}$ of a S. aureus SA113 overnight culture were centrifuged $(7000 \times g$ for $20 \mathrm{~min})$, and the pellet was resuspended in PBS to an $\mathrm{OD}_{600 \mathrm{~nm}}$ of 1 . The flow cells were first filled with PBS, followed by the S. aureus suspension for $20 \mathrm{~min}$ at a flow rate of $570 \mu \mathrm{L} / \mathrm{min}$ (resulting in shear forces of $10^{-2} \mathrm{~Pa}$ ), and then incubated for $20 \mathrm{~h}$ at $4{ }^{\circ} \mathrm{C}, 10^{\circ} \mathrm{C}, 19^{\circ} \mathrm{C}$ (chosen as the standard procedure after preliminary experiments), $25^{\circ} \mathrm{C}$ or $37{ }^{\circ} \mathrm{C}$ under constant flow $(570 \mu \mathrm{L} / \mathrm{min})$ of TSBG. Flow cells were then disassembled, the glass slides containing the biofilms washed in PBS and subsequently submerged in solutions of LysK and/or DA7 or buffer as a control for 2 or $5 \mathrm{~h}$ at $25^{\circ} \mathrm{C}$. Following treatment, the slides were washed with PBS, and residual biofilm on the slides was quantified by CV staining as described above for the static biofilm model. Alternatively, the number of residual viable $S$. aureus cells on the slides was determined by vortexing the glass slides with $5 \mathrm{~mL}$ of Marienfeld Superior soda lime glass beads (Fisher Scientific) in $30 \mathrm{~mL}$ PBS for $30 \mathrm{~s}$ and plating serial dilutions of the supernatant on agar plates for enumeration of colonies.

\subsection{Determination of Synergy between LysK and DA7}

To determine synergistic effects between LysK and DA7 against S. aureus biofilms in a static model, 2-fold serial dilutions of both enzymes starting with their respective minimum biofilm eradication concentrations (MBECs) as highest concentrations were prepared. The MBEC was defined as the lowest concentration of an agent required to remove all visible biofilm from the polystyrene surface in the static biofilm reduction assay as described above. The efficacies of these serially diluted individual enzymes (MBECs $x$ and $y$ ) at removing static $S$. aureus biofilms were then compared to those of 2-fold serially diluted mixtures of both enzymes at different ratios $\left(\frac{1}{2} x+\frac{1}{2} y, \frac{3}{4} x+\frac{1}{4} y\right.$, and $\left.\frac{1}{4} x+\frac{3}{4} y\right)$. For each mixture, the sum of fractional biofilm eradication concentrations ( $\Sigma F B E C$; corresponding to the sum of fractional inhibitory concentrations, $\Sigma$ FIC, in a classical microdilution broth synergy assay $[40,41])$ as a measure of synergy was calculated from the difference between the row containing the first cleared well for the enzyme mixture and the row containing the first cleared wells for the single enzymes [37]. In analogy to the classical synergy assays, enzyme combinations with a $\Sigma F B E C$ below 0.5 were considered synergistic [41]. To determine synergistic effects in the dynamic model, the $S$. aureus biofilm was grown in 4 parallel flow cells as described above and treated with buffer (control), DA7 (concentration $x$ ), LysK (concentration y), or a mixture of DA7 and LysK $\left(\frac{1}{4} x+\frac{3}{4} y\right)$ for $2 \mathrm{~h}$ at room temperature. For each treatment, residual viable $S$. aureus cells were determined as described above. 


\subsection{Confocal Laser Scanning Microscopy}

For confocal laser scanning microscopy (CLSM), S. aureus biofilms were grown essentially as described above for the dynamic biofilm model with some modifications. Instead of Biostream flow cells, 8-cell $\mu$-Slide VI ${ }^{0.4}$ flow cells (IBIDI, Martinsried, Germany) were used. Due to the smaller dimensions of these cells, the flow rate was reduced to $60 \mu \mathrm{L} / \mathrm{min}$ in an effort to achieve similar shear forces $\left(10^{-2} \mathrm{~Pa}\right)$ as in the Biostream setup. Biofilms were washed with PBS at the same flow rate before filling the cells with enzyme solution and incubating them without flow for $2 \mathrm{~h}$ at $25^{\circ} \mathrm{C}$. After treatment, the cells were washed again, and residual biofilms in the cells were stained with live/dead stain (LIVE/DEAD BacLight; Life Technologies, Carlsbad, CA, USA) diluted 1:1 with PBS for $15 \mathrm{~min}$. After another wash with PBS, biofilms were visualized by CLSM, using a Leica TCS SPE system (Leica Microsystems, Wetzlar, Germany). Three-dimensional reconstructions of biofilms were generated in silico from recorded z-stacks using the software ImageJ [42].

\subsection{Statistical Analysis}

One-way analysis of variance (ANOVA) with a post hoc Tukey honestly significant difference (HSD) test was used for multiple means comparisons or Welch's $t$-test for two-mean comparisons in dynamic biofilm reduction experiments.

\section{Results}

\subsection{The Bacteriophage Endolysin LysK Is Active against Biofilms of Multiple S. aureus Strains}

To determine the activity of LysK against biofilms of multiple $S$. aureus strains, a selection of strains from our laboratory collection (Table 1) was first assessed for their ability to form biofilms on polystyrene surfaces in a static 96-well plate-based model. These included SA113, a reportedly strong biofilm former and producer of PNAG [32,43], which served as a positive control in this experiment; three bovine mastitis isolates from different geographic regions; multiple food isolates; and RN6911, a mutant strain deficient of the accessory gene regulator (agr) [33]. Expression of this regulator results in enhanced biofilm dispersal [44] and, therefore, the mutant strain was expected to be a strong biofilm producer. In fact, RN6911 demonstrated the best biofilm forming ability of all tested strains, as revealed by $\mathrm{CV}$ staining of biofilms grown for $24 \mathrm{~h}$ at $30^{\circ} \mathrm{C}$ (Figure $1 \mathrm{~A}$ ). In addition, SA113, the mastitis strain SA001, and the food isolates R174 and R177 were found to produce strong biofilms. The remaining strains were classified as moderate biofilm formers, with the exception of strain 350, which only produced weak biofilms. We then tested the efficacy of LysK against biofilms of each of these strains in the static model. To this end, the biofilms were exposed to two-fold serial dilutions of the endolysin for $2.5 \mathrm{~h}$, and residual biofilms were stained with $\mathrm{CV}$ and quantified spectrophotometrically, as exemplified for SA113 in Figure 1B. The susceptibility of each strain to LysK degradation was rated based on the concentration-dependent reduction in biofilm mass (Figure 1A). The majority of strains were highly susceptible to the action of the endolysin, with concentrations as low as $40 \mathrm{nM}$ causing a reduction in biofilm mass. Only strains Newbould and R174 showed a higher degree of recalcitrance to the enzyme, with none of the tested enzyme concentrations reducing the biofilm by more than $40 \%$. 
A

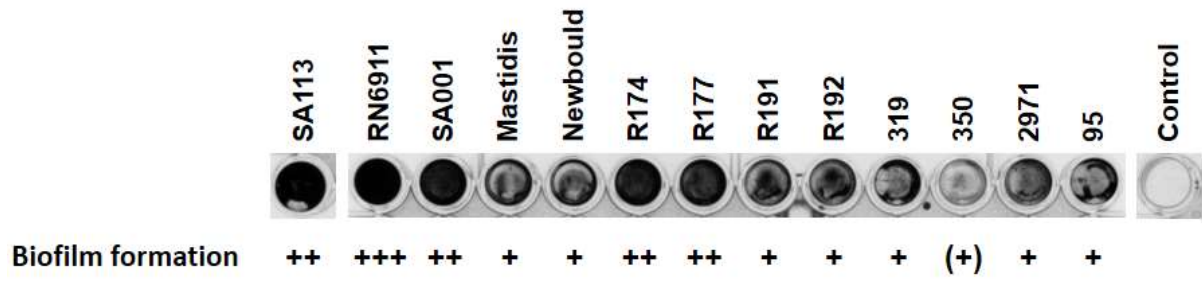

LysK efficacy

$+++\quad+++++(+)(+)+++++++++++++$

B

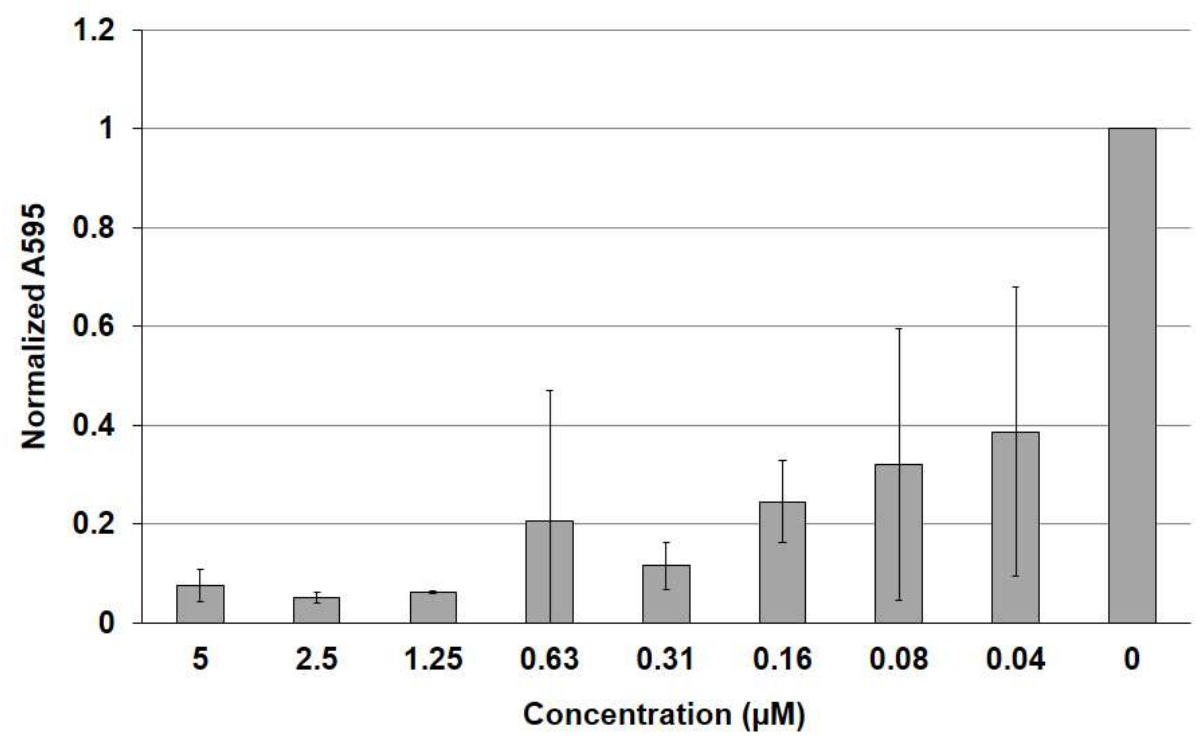

Figure 1. Activity of LysK against biofilms of various S. aureus strains in a static model. (A) Biofilm formation and susceptibility to LysK treatment of various S. aureus strains. Biofilms were grown statically in 96-well plates for $24 \mathrm{~h}$ at $30{ }^{\circ} \mathrm{C}$ and stained with $\mathrm{CV}$. The strains were rated for their biofilm forming ability based on $\mathrm{A}_{595 \mathrm{~nm}}$ measurements of solubilized $\mathrm{CV}$ as follows: +++ , very strong $\left(\mathrm{A}_{595 \mathrm{~nm}}>3\right) ;++$, strong $\left(\mathrm{A}_{595 \mathrm{~nm}}>1\right) ;+$, moderate $\left(\mathrm{A}_{595 \mathrm{~nm}}>0.2\right) ;(+)$, weak $\left(\mathrm{A}_{595 \mathrm{~nm}} \leq 0.2\right)$. At least three experiments were conducted, and one representative well for each strain is shown (top). Efficacy of LysK against biofilms of each strain was determined as exemplified for SA113 in (B) and rated as follows (bottom):,$+++>40 \%$ reduction in $\mathrm{A}_{595 \mathrm{~nm}}$ compared to the control at a concentration (c) $\leq 0.08 \mu \mathrm{M} ;++,>40 \%$ reduction at $\mathrm{c} \leq 0.31 \mu \mathrm{M} ;+,>40 \%$ reduction at $\mathrm{c} \leq 1.25 \mu \mathrm{M} ;(+)$, no reduction $>40 \%$ even at c > $1.25 \mu \mathrm{M}$. (B) S. aureus SA113 biofilms grown in a 96-well plate for $24 \mathrm{~h}$ at $30{ }^{\circ} \mathrm{C}$ were treated with LysK at different concentrations or buffer as a control (0) for $2.5 \mathrm{~h}$, and residual biofilms after treatment were stained with crystal violet (CV). After dissolving the CV in $96 \%$ ethanol, the $A_{595 n m}$ of each well was measured spectrophotometrically. All values were normalized to the control. Error bars indicate standard deviations from three independent experiments.

\subsection{LysK Degrades S. aureus Biofilms Grown under Dynamic Conditions}

The static biofilm reduction assay as described above has been used most frequently in previous studies evaluating the efficacy of endolysins against bacterial biofilms [21,23-25], and it represents a valid method to assess the general capability of an enzyme to degrade biofilms. However, this model inadequately mimics situations frequently encountered in clinical and veterinarian settings as well as food processing, where biofilms are often exposed to shear forces due to the constant flow of 
liquids. To better account for these factors, we tested the efficacy of LysK against $S$. aureus biofilms grown under dynamic conditions, using a Biostream flow cell assembly. In a series of preliminary experiments, biofilm growth of $S$. aureus SA113 within $20 \mathrm{~h}$ in this setup was evaluated at various different temperatures ranging from $4{ }^{\circ} \mathrm{C}$ to $37^{\circ} \mathrm{C}$. While incubation at $4{ }^{\circ} \mathrm{C}$ resulted in no visible biofilm growth under the applied conditions, incubation at $37^{\circ} \mathrm{C}$ yielded large bacterial aggregates. However, these often showed insufficient attachment to the glass surface, which resulted in frequent clogging of the flow cell and an overall low reproducibility of the experiments [45]. The temperature that yielded the best results in terms of reproducibility and, at the same time, represented a reasonable compromise between biomass production and stable attachment to the surface was $19{ }^{\circ} \mathrm{C}$. For these reasons, this incubation temperature was chosen for all further dynamic biofilm experiments in this study. When SA113 biofilms grown under these conditions were submerged in LysK solutions of various concentrations (ranging from 0.31 to $1.25 \mu \mathrm{M}$ ) for $5 \mathrm{~h}$, we observed a concentration-dependent removal of the biofilms from the glass surfaces, as demonstrated by $\mathrm{CV}$ staining of residual biofilms followed by spectrophotometric quantification of the solubilized stain (Figure 2A,C).

A

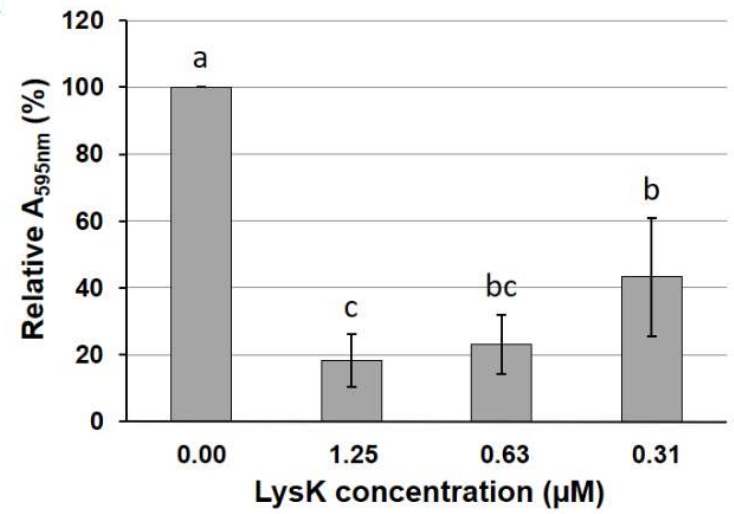

C

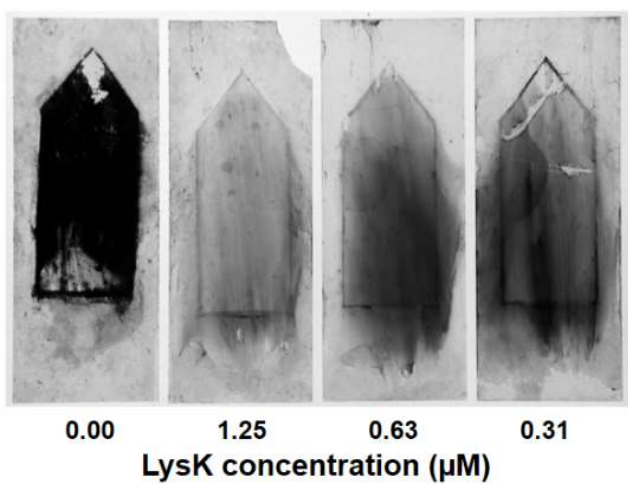

B

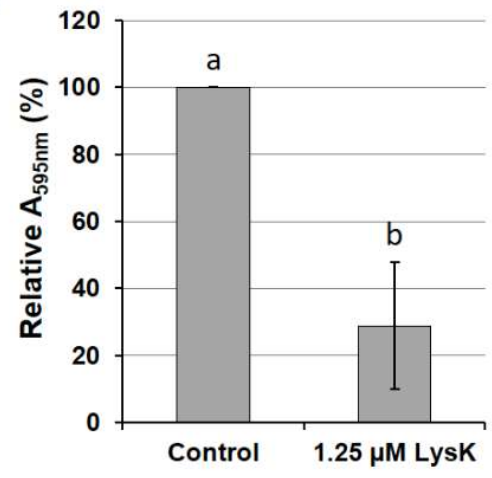

D

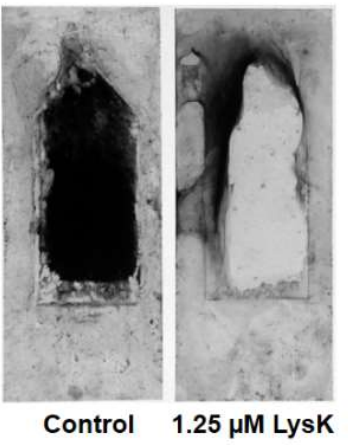

Figure 2. Efficacy of LysK against dynamic S. aureus SA113 biofilms grown on glass surfaces in the Biostream flow cell. Biofilms were grown for $20 \mathrm{~h}$ at $19{ }^{\circ} \mathrm{C}$ under continuous flow of medium. Glass slides were then submerged in solutions of LysK at different concentrations or buffer as a control for $5 \mathrm{~h}(\mathbf{A}, \mathbf{C})$ or $2 \mathrm{~h}(\mathbf{B}, \mathbf{D})$, and stained with crystal violet. The stain was dissolved in $96 \%$ ethanol and the $\mathrm{A}_{595 \mathrm{~nm}}$ measured spectrophotometrically $(\mathbf{A}, \mathbf{B})$. All values were normalized to the control. Error bars indicate standard deviations from at least three independent experiments. Bars with different letters are significantly different from each other $(p<0.05)$. Representative glass slides after washing and before solubilization of the stain are shown for the $5 \mathrm{~h}(\mathrm{C})$ and the $2 \mathrm{~h}(\mathrm{D})$ treatments.

Both 1.25 and $0.63 \mu \mathrm{M}$ LysK caused a reduction in the $A_{595 \mathrm{~nm}}$ by approximately $80 \%$ compared to the control (biofilms submerged in buffer without enzyme). At an endolysin concentration of $0.31 \mu \mathrm{M}$, 
the biofilm-disrupting effect was markedly reduced (approximately $60 \%$ reduction compared to the control). When the incubation time was shortened to $2 \mathrm{~h}, 1.25 \mu \mathrm{M}$ LysK was still able to decrease the $A_{595 \mathrm{~nm}}$ by more than $70 \%$, which was not significantly different $(p>0.05)$ from the $5 \mathrm{~h}$ treatment. Therefore, the $2 \mathrm{~h}$ incubation was adopted as the standard procedure in the subsequent experiments.

\subsection{A. actinomycetemcomitans-Derived PNAG Depolymerases Disrupt S. aureus Biofilms}

In an effort to identify agents with the ability to disrupt the extracellular matrix of $S$. aureus biofilms, putative PNAG depolymerases from five different $A$. actinomycetemcomitans strains (Table 1) were cloned and produced in $E$. coli as $\mathrm{N}$ - and C-terminally $6 \times$ His-tagged recombinant proteins. Cloning, expression, and purification by IMAC was successful for 7 out of 10 constructs, and nucleotide sequencing revealed high similarity $(>90 \%)$ of all proteins with the previously described PNAG depolymerase dispersin B [27]. Cloning was not successful for the remaining three constructs.

All purified depolymerases were then compared for their ability to remove $S$. aureus biofilms in the static model. While all C-terminally His-tagged enzymes exhibited approximately two-fold higher activity than their N-terminally His-tagged counterparts, no significant differences in activity within the group of N-terminally His-tagged proteins or within the group of C-terminally His-tagged proteins were found [45]. Therefore, one of the C-terminally His-tagged depolymerases, DA7, which was consistently produced at high yields and purity (Figure 3A), was selected for further analysis. DA7 demonstrated high biofilm-disrupting activity, removing statically grown biofilms from polystyrene surfaces at low nanomolar concentrations (MBEC $2.5 \mathrm{nM}$; Figure 3B,C). In addition, in the dynamic model, DA7 eliminated all visible biofilm at concentrations as low as $6.25 \mathrm{nM}$ (Figure S1).

A

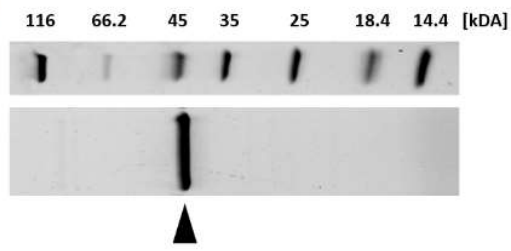

B

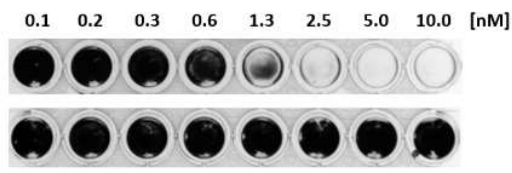

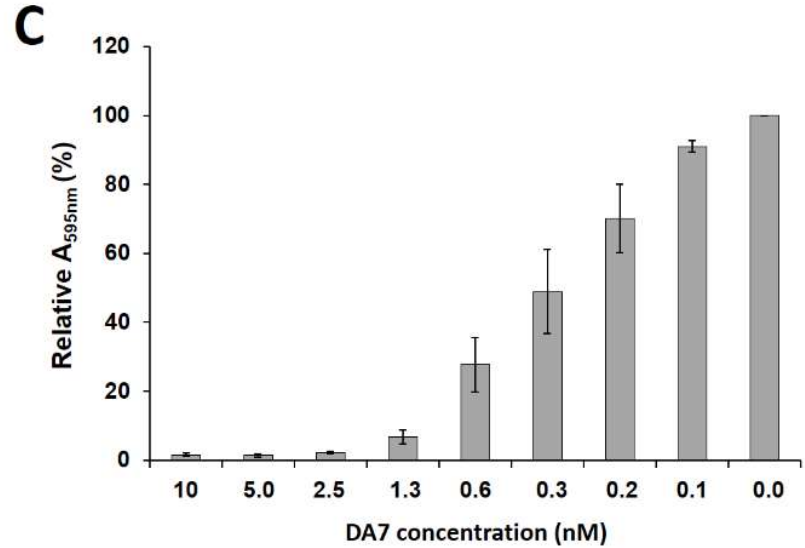

DA7 concentration (nM)

Figure 3. Purification and anti-biofilm activity of the polysaccharide depolymerase DA7. (A) Sodium dodecyl sulfate polyacrylamide gel electrophoresis (SDS-PAGE) of purified DA7 protein. The band of interest (expected molecular weight: $42.1 \mathrm{kDa}$ ) is marked by an arrow. (B) Static S. aureus SA113 biofilms were grown at $30^{\circ} \mathrm{C}$ for $24 \mathrm{~h}$, treated with increasing concentrations of DA7 (top) or buffer as a control (bottom) for $30 \mathrm{~min}$ at $30^{\circ} \mathrm{C}$, and stained with crystal violet $(\mathrm{CV})$. (C) Relative $\mathrm{A}_{595 \mathrm{~nm}}$ values measured after dissolving the CV stain on residual biofilms in $96 \%$ ethanol after DA7 treatment as shown in panel B. Values are normalized to the control, and error bars represent standard errors of the mean from three independent experiments.

\subsection{DNase I Is Active against S. aureus SA113 Biofilms at High Concentration}

Besides exopolysaccharides and proteins, extracellular DNA has been reported to be an important component of staphylococcal biofilms [46]. Aiming at a multi-enzyme approach in which various components of the extracellular matrix of S. aureus biofilms are targeted simultaneously, we evaluated the effect of DNase I against SA113 biofilms grown in the static model. Similar to our observations with DA7, DNAse I caused a concentration-dependent removal of the biofilms from the polystyrene surfaces (Figure S2). However, the DNAse I concentrations required to achieve effects similar to those 
of DA7 were relatively high, with an MBEC of $250 \mu \mathrm{g} / \mathrm{mL}$ (approximately $8 \mu \mathrm{M}$ ), compared to $2.5 \mathrm{nM}$ for DA7. For this reason, the inclusion of DNAse I in a combination treatment with LysK was not further pursued.

\subsection{LysK and DA7 Act Synergistically to Degrade S. aureus Biofilms in Both Static and Dynamic Models}

The high efficacy of the depolymerase DA7 at removing S. aureus biofilms in both static and dynamic models led us to investigate the effect of a combined treatment with LysK and DA7 in an effort to achieve enhanced degradation of biofilm mass besides inactivation of staphylococcal cells. To this end, the efficacies of the two individual enzymes against SA113 biofilms were compared with those of enzyme mixtures at different ratios in the static biofilm model (Figure 4A). The mean $\Sigma$ FBEC values obtained for the combination treatment with DA7 and LysK at the ratios 50:50, 75:25, and 25:75 in these experiments were $0.38 \pm 0.14,0.50 \pm 0.00$, and $0.31 \pm 0.13$, respectively, suggesting a synergistic effect of the two enzymes against SA113 biofilms. Based on these results, we further explored whether this synergistic effect can also be observed against biofilms grown under dynamic conditions. Therefore, SA113 biofilms grown on glass slides in four parallel Biostream flow cells were exposed to either buffer as a control, DA7, LysK, or a mixture of both enzymes at the ratio of 25:75, which had proven most effective in the static model. Residual biofilms after treatment were recovered from the glass slides and the concentrations of viable bacteria determined. All enzyme treatments significantly reduced the number of viable cells on the glass slides compared to the control treatment, with the DA7/LysK combination treatment being most effective (Figure 4B). The enzyme mixture caused a reduction in $\mathrm{CFU} / \mathrm{mL}$ by approximately $2.5 \mathrm{log}$ units, which was significantly $(p<0.05)$ more than the reductions caused by either individual enzyme treatment and is in agreement with the results from the static synergy assays.

A

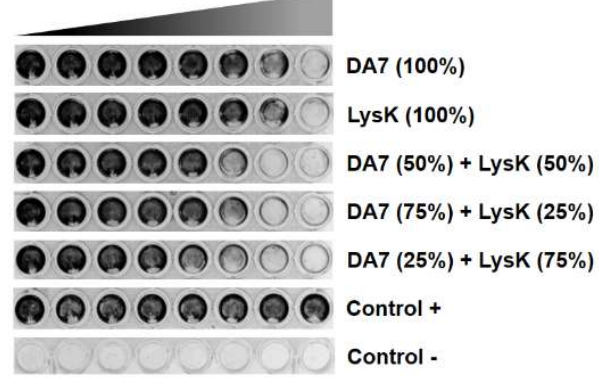

B

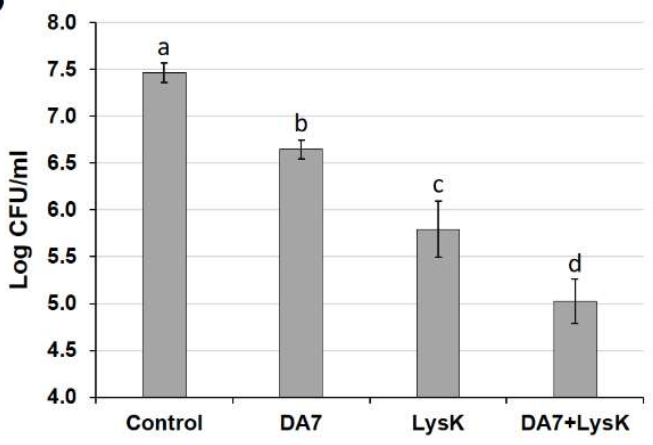

Figure 4. Synergistic effect of DA7 and LysK against S. aureus biofilms in static and dynamic models. (A) SA113 biofilms grown statically in 96-well plates were treated with two-fold serial dilutions of DA7, LysK, and mixtures of both enzymes at the ratios 50:50, 75:25, and 25:75, with the highest concentrations on the right and the lowest concentrations on the left of each row. After treatment, residual biofilms were stained with crystal violet. For each individual enzyme, the highest concentration used was the respective minimum biofilm eradication concentration (MBEC) and was defined as $100 \%$. Highest concentrations of enzymes within mixtures are expressed as percentages of the respective MBECs. (B) Residual viable $S$. aureus on the glass surface of the Biostream flow cell after a $2 \mathrm{~h}$ treatment of dynamic biofilms with buffer (control), DA7 (0.625 nM), LysK $(1.25 \mu \mathrm{M})$, or a combination of both $(0.156 \mathrm{nM}$ DA7 + $0.938 \mu \mathrm{M}$ LysK, corresponding to a ratio of 25:75). Error bars represent standard deviations from at least seven independent experiments. Bars with different letters are significantly different from each other $(p<0.05)$.

To visualize the synergistic effect observed in both static and dynamic models, we performed CLSM on $S$. aureus biofilms grown under dynamic conditions in IBIDI $\mu$-slides. Similar to the experiments in the Biostream flow cell, the biofilms were treated with buffer, DA7, LysK, or a mixture of 
both enzymes, and residual bacterial cells in the $\mu$-slides after treatment were live/dead stained prior to microscopy. Three-dimensional reconstructions of the biofilms after various treatments generated from recorded z-stacks are shown in Figure 5. Compared to the control treatment (Figure 5A), exposure to DA7 resulted in a reduced thickness of the biofilm adhering to the slide by approximately $50 \%$. However, the depolymerase had no visible effect on the viability of the residual cells (Figure 5B). In contrast, LysK killed the majority of the bacteria, including those close to the bottom of the biofilm, suggesting that the endolysin is able to deeply penetrate the biofilm and exert its bactericidal effect. Despite this strong killing activity, many of the dead cells (and/or extracellular DNA released upon cell lysis) appeared to remain bound within the residual biomass attached to the slides (Figure 5C). When biofilms were exposed to a mixture of DA7 and LysK at the ratio 25:75, both the overall bacterial density on the slide surface and the number of viable cells remaining after treatment were markedly reduced compared to the control, underlining the synergistic effect of the depolymerase and the endolysin against $S$. aureus biofilms.
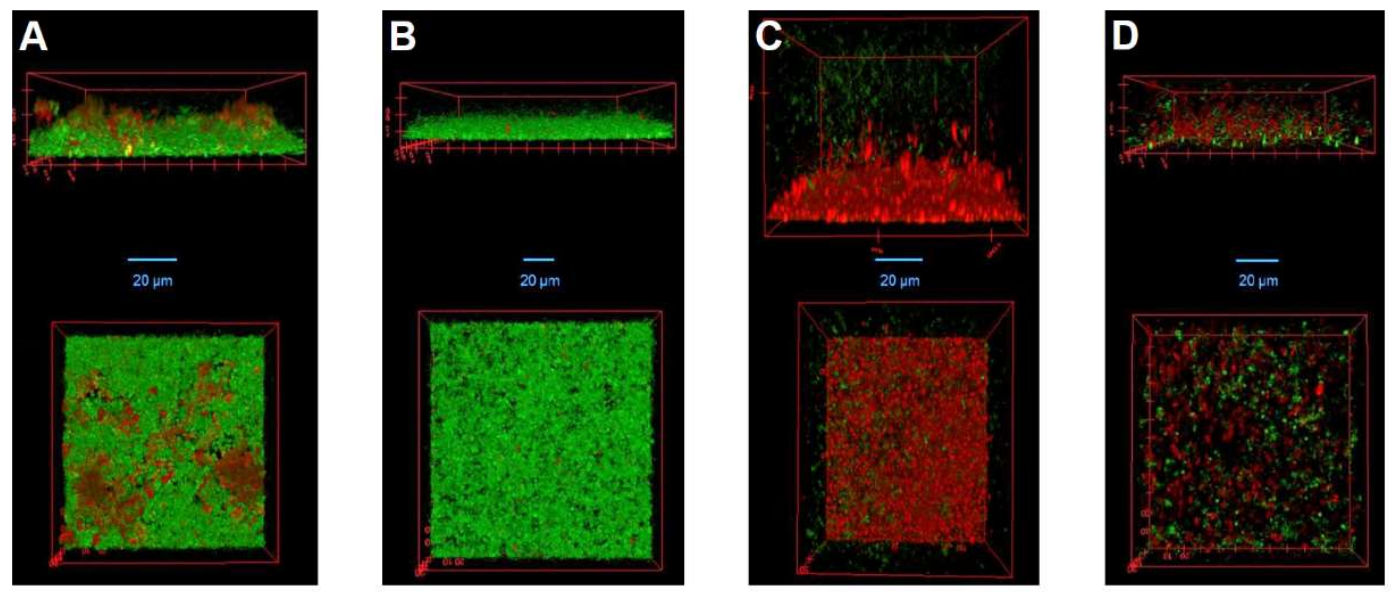

Figure 5. Confocal laser scanning micrographs of S. aureus biofilms treated with DA7, LysK, or a combination of both agents. SA113 biofilms were grown in IBIDI $\mu$-slides for $20 \mathrm{~h}$ at $19{ }^{\circ} \mathrm{C}$ and then treated for $2 \mathrm{~h}$ with: buffer (A); $0.625 \mathrm{nM}$ DA7 (B); $1.25 \mu \mathrm{M}$ LysK (C); or a combination of $0.156 \mathrm{nM}$ DA7 and $0.938 \mu \mathrm{M}$ LysK (D). Residual biofilms after treatment were stained with LIVE/DEAD stain and then visualized by CLSM. Side views (top); and top views (bottom) of biofilm 3D reconstructions are shown. Live cells are depicted in green and dead cells as well as extracellular DNA in red.

\section{Discussion}

Bacterial biofilms are complex structures consisting of bacterial cells surrounded by a protective extracellular matrix composed of various macromolecules such as DNA, proteins, and exopolysaccharides. This network of intertwined biopolymers provides stability, contributes to cohesion of cells and adhesion to various biotic and abiotic surfaces, and limits diffusion of molecules into the biofilm [10]. This being said, it seems evident that targeting and degrading several different polymeric components of a biofilm simultaneously constitutes a promising strategy to effectively disintegrate these multi-component structures in order to eradicate unwanted bacteria. In this study, we evaluated the efficacy of the bacteriophage endolysin LysK to degrade biofilms of the important human pathogen $S$. aureus, alone and in combination with a depolymerase that digests an abundant exopolysaccharide in the biofilm matrix. It is important to note that endolysins not only kill their target cells but also further disintegrate the peptidoglycan sacculi of the dead bacteria, which by themselves constitute an important structural component of a biofilm, thereby disrupting the integrity of the entire structure.

An increasing number of studies in recent years have investigated the efficacy of various phage-derived lytic enzymes against staphylococcal biofilms [23,24,47-53]. The majority of these 
studies employed microtiter plate-based biofilm models or other static setups, and there is a general lack of endolysin efficacy studies against dynamically grown biofilms using flow cell models. One exception is a recent study by Becker et al., who reported that chimeric peptidoglycan hydrolases featuring three unique enzymatic activities were able to reduce the concentration of viable cells in $S$. aureus biofilms dynamically grown within a commercial microchannel flow cell by up to $0.89 \log$ units within $2 \mathrm{~h}$ at a concentration of $1.4 \mu \mathrm{M}$ [50]. As opposed to such microchannel systems, the Biostream flow cell used here has a volume of approximately $1 \mathrm{~mL}$ and allows removal of the biofilm contact surface without the necessity to break parts of the assembly. This system ensures a linear flow profile over the entire width of the chamber [31], simulating flow conditions as they are expected to occur in the bloodstream, in food processing facilities, or in milk canals within the bovine udder. When S. aureus biofilms grown under these conditions were treated with LysK at a concentration of $1.25 \mu \mathrm{M}$ for $2 \mathrm{~h}$, the number of residual viable cells on the slides was reduced by approximately 1.7 logs (Figure 4B). CV staining of LysK-treated biofilms revealed a noticeable difference in the way the biofilms were removed from the glass slides between the $2 \mathrm{~h}$ and the $5 \mathrm{~h}$ treatments (Figure 2). Although the overall reduction in biomass was similar for both treatment times, biofilms exposed to the endolysin for $2 \mathrm{~h}$ were sloughed off the surface in large fragments when applying mechanical forces during the post-treatment washes. In contrast, biofilms treated for $5 \mathrm{~h}$ showed a higher degree of stickiness, leaving thin layers of biomass on the slides after the washing step. This could be explained by increased release of DNA from dead bacterial cells that are exposed to the endolysin for extended periods of time. This is in agreement with the DA7-mediated biofilm removal, where no such sticky residues were observed (Figure S1). Due to its activity against the extracellular biofilm matrix but not the staphylococcal cells, no increase in extracellular DNA is to be expected in this case.

Despite our efforts to apply similar shear forces to growing biofilms in the Biostream flow cell and the IBIDI $\mu$-slides used for CLSM, it cannot be ruled out that biofilms produced in the two systems are different, particularly regarding their 3D structure. However, the finding that the results obtained in the CLSM experiments for the different treatments are largely in agreement with those obtained with the Biostream flow cell argues against a significant impact of the flow cell system used on the susceptibility of the produced biofilms to the enzymes.

Given the high degree of similarity of DA7 and other A. actinomycetemcomitans-derived depolymerases investigated in this work with the previously described dispersin B [27], it is safe to assume that these proteins exhibit the same enzymatic specificity and mechanism of action in hydrolyzing poly- $\beta(1,6)-N$-acetyl-D-glucosamine present in the extracellular biofilm matrix of many staphylococcal strains [54]. This also explains why all depolymerases within the group of C-terminally His-tagged proteins showed similar levels of efficacy against static biofilms, and the same was true for all depolymerases within the group of N-terminally His-tagged proteins [45]. However, there was a consistent difference in activity between the C-terminally His-tagged versions of the enzymes and their N-terminally His-tagged counterparts [45]. The most likely reason for the reduced activity of the latter versions is that a His-tag fused to the N-terminus of the enzyme interferes with the conformation of the protein in an unfavorable manner or impedes access of the substrate to the catalytic center. This is in line with the finding that the enzymatically active site of dispersin B is located in the N-terminal portion of the enzyme [55].

When compared on a molar basis, the capacity of DA7 to remove $S$. aureus biomass from glass and polystyrene surfaces surpasses that of LysK by several orders of magnitude in both static and dynamic models. However, it should not be forgotten that DA7 is not bactericidal, whereas the endolysin LysK effectively kills $S$. aureus even within deeper layers of the biofilm, as demonstrated by CLSM of live/dead-stained biofilms (Figure 5). Furthermore, endolysins have been reported to be active against persister cells, a capability of high relevance in the context of biofilms, which are known to harbor a high proportion of slow- or non-growing bacteria [23]. This clearly argues for a combined application of endolysins and depolymerases, as has been investigated for LysK and DA7 in this work. The synergistic effect of these two enzymes used in combination against $S$. aureus 
biofilms was demonstrated in both static and dynamic models. It can most likely be attributed to facilitated access for LysK to $S$. aureus cells embedded within the biofilm matrix when PNAG, an important component of this matrix, is degraded by DA7. Likewise, disintegration of bacterial cell walls by LysK may enable DA7 to penetrate into deeper layers of the biofilm, which overall leads to a more effective destabilization of the three-dimensional structure. Besides the observed synergy, the activities of the individual enzymes were found to be similar when comparing static and dynamic models. In both cases, LysK and DA7 removed the majority of visible biofilm at low micromolar and low nanomolar concentrations, respectively, suggesting that dynamically grown biofilms do not show a substantially higher level of recalcitrance against the enzymes under the conditions applied here. While different surface materials may affect the adhesion capacity of bacterial cells, it has been suggested that polystyrene (as used in our static model) and glass (as used in the Biostream flow cell) do not significantly differ in the attachment capacity of various organisms, including S. aureus [56]. However, it should be noted that direct comparison of results from the static and dynamic models is difficult due to the different growth and treatment conditions applied in the two models.

Staining of biofilms with CV as it has been applied here in both static and dynamic models is one of the most widely used methods for quantification of adhered biomass. It offers several advantages such as versatility and high throughput capability. Furthermore, it avoids the necessity to detach biofilms from their growth surfaces, as required for enumeration of viable cells. At the same time, one needs to be aware of the drawbacks of this method. These include a lack of reproducibility and sensitivity and a possible over- or underestimation of biofilm mass in dependence of the washing steps (reviewed in [57]).

S. aureus strain SA113, which was used in most static and dynamic biofilm experiments in this study, is a reportedly strong biofilm former that is known to produce PNAG as a major component of its extracellular matrix [43]. This explains the high efficacy of the PNAG-depolymerase DA7 against SA113 biofilms, as shown here. At the same time, it implies that DA7 is inactive against biofilms of S. aureus strains incapable of PNAG production or for which PNAG is not a major extracellular matrix component, as has been demonstrated for the DA7-homologue dispersin B [58]. It is important to note that the $i c a A D B C$ locus, which is responsible for PNAG production, is present in the majority of all S. aureus clinical isolates [59], and that production of PNAG has been shown to be a crucial factor for S. aureus pathogenesis in murine models of systemic infection [60] and in S. aureus-induced bovine mastitis [14]. One non-dispersin B-like exopolysaccharide depolymerase named Dpo7 with activity against $S$. aureus biofilms has recently been described [29]. However, the exact molecular target of this phage-derived enzyme is still unknown.

Aiming at a multi-enzyme approach to eradicate $S$. aureus biofilms, we also investigated the ability of DNase I to reduce SA113 biofilms by degrading extracellular DNA. Our results are in agreement with previous studies, which had found that DNase I compromised the integrity of biofilms formed by various $S$. aureus strains, leading to their detachment $[26,58,61]$. However, under the conditions applied in our work, the DNase I concentrations required to achieve similar effects as for DA7 were more than 1000-fold higher when compared on a molar basis. Therefore, DNase I was not included in the synergy experiments in this study. However, similar to what has been discussed for DA7, susceptibility to DNase I can vary from strain to strain, likely depending on the proportion of extracellular DNA within the biofilm matrix.

Strain-dependent differences in efficacy against S. aureus biofilms were also observed for LysK, even though the endolysin displayed strong activity against the majority of the strains tested here in the static model. This is consistent with a previous report, in which the staphylococcal phage endolysin LysGH15 was shown to degrade biofilms of more than 30 staphylococcal strains from different species (S. aureus, S. epidermidis, S. hominis, and S. haemolyticus) grown for 24 or $72 \mathrm{~h}$ in a static model [47]. LysGH15 is almost identical with LysK, differing from the latter in only four amino acids [19]. Furthermore, LysK has demonstrated strong lytic activity against planktonic cells of a large set of staphylococcal strains, including clinical S. aureus isolates (MSSA and MRSA), bovine 
mastitis isolates, coagulase-negative staphylococci, and multiple mutant strains with altered surface structures [21]. Taken together, these results provide further evidence that LysK is a potent staphylolytic enzyme with a broad spectrum of activity against planktonic cells and biofilms. However, further studies are required to investigate whether this holds true when LysK is used against dynamically grown biofilms of multiple strains, alone or in combination with DA7.

It is important to understand that the growth conditions (and growth temperatures in particular) applied in the biofilm experiments in this work were not chosen in order to optimally simulate conditions found in either clinical/veterinarian or food safety environments or to allow direct comparison between the static and dynamic models, but in an effort to produce the most stable and reproducible biofilms within each given setup. When aiming at specific applications in either of these settings, further experiments beyond the scope of the current study are advisable. These could include investigating the impact of various parameters such as media composition, growth temperature, incubation time, surface material and surface coatings on the growth of S. aureus biofilms and their susceptibility to LysK and DA7. Further, it could be relevant to investigate mixed-species biofilms and their susceptibility to these combined treatment strategies, since they are prevalent in most settings outside the laboratory [62,63]. Moreover, it could be interesting, at least from a scientific perspective, to assess the potential of both enzymes to prevent biofilm growth as opposed to disruption of mature biofilms. While preventive application may not be viable in food production due to the high costs associated with it, it may be feasible in certain niche medical applications, e.g., following surgery for insertion of prosthetic joints or catheters.

In the context of medical and veterinarian applications, a combination of our enzyme-based approach with classical antibiotic treatment, as has been suggested previously [64], could constitute an effective therapy against $S$. aureus infections involving biofilms. In bovine mastitis treatment, biofilm-degrading enzymes could contribute to the declogging of milk ducts congested by aggregates of bacterial and somatic cells in order to facilitate penetration of the udder by antibacterial agents administered intramammarily. Finally, biofilm-disrupting enzymes could be part of an effective hurdle technology applied in food production and processing facilities to alleviate the risk of biofilm-mediated contamination of food products.

Supplementary Materials: The following are available online at http:/ / www.mdpi.com/1999-4915/10/8/438/s1: Figure S1: Efficacy of DA7 against dynamic S. aureus SA113 biofilms grown on glass surfaces in the Biostream flow cell. Figure S2: Activity of DNAse I against S. aureus SA113 biofilms grown in a 96-well plate under static conditions.

Author Contributions: N.M.C.O., E.T., T.V., G.N.B. and M.S. conceived and designed the experiments; N.M.C.O., E.T. and T.H. performed the experiments; N.M.C.O., E.T., T.H. and M.S. analyzed the data; G.N.B., J.M. and M.J.L. contributed reagents/materials/analysis tools; and N.M.C.O. and M.S. wrote the paper.

Funding: This research was funded by a grant from Swiss Food Research (Swiss Food Research Call 2012, to M.S.) and a grant from the Belgian Fonds de la Recherche Scientifique (F.R.S.-FNRS, to T.V.).

Conflicts of Interest: M.J.L. is an advisor for Micreos, a company producing phage-based antimicrobials. T.V. is currently an employee of OneLife, a company producing enzymatic solutions against biofilms. However, the employment started after the completion of the current study, and OneLife had no role in the design of the study; in the collection, analyses, or interpretation of data; in the writing of the manuscript, and in the decision to publish the results. The same is true for all funding sponsors. The other authors declare no conflict of interest.

\section{References}

1. Götz, F.; Bannerman, T.; Schleifer, K.H. The Genera Staphylococcus and Macrococcus. In The Prokaryotes; Falkow, S., Rosenberg, E., Schleifer, K.H., Stackebrandt, E., Eds.; Springer: New York, NY, USA, 2006; Volume 4, pp. 5-75.

2. Lowy, F.D. Staphylococcus aureus infections. N. Engl. J. Med. 1998, 339, 520-532. [CrossRef] [PubMed]

3. Thurnheer, T.; Belibasakis, G.N. Integration of non-oral bacteria into in vitro oral biofilms. Virulence 2015, 6, 258-264. [CrossRef] [PubMed] 
4. Thurnheer, T.; Belibasakis, G.N. Incorporation of staphylococci into titanium-grown biofilms: An in vitro "submucosal" biofilm model for peri-implantitis. Clin. Oral Implants Res. 2016, 27, 890-895. [CrossRef] [PubMed]

5. Charalampakis, G.; Belibasakis, G.N. Microbiome of peri-implant infections: Lessons from conventional, molecular and metagenomic analyses. Virulence 2015, 6, 183-187. [CrossRef] [PubMed]

6. Fisher, E.L.; Otto, M.; Cheung, G.Y.C. Basis of Virulence in Enterotoxin-Mediated Staphylococcal Food Poisoning. Front. Microbiol. 2018, 9, 436. [CrossRef] [PubMed]

7. Sordillo, L.M.; Streicher, K.L. Mammary gland immunity and mastitis susceptibility. J. Mammary Gland Biol. Neoplasia 2002, 7, 135-146. [CrossRef] [PubMed]

8. Ben-David, D.; Novikov, I.; Mermel, L.A. Are there differences in hospital cost between patients with nosocomial methicillin-resistant Staphylococcus aureus bloodstream infection and those with methicillin-susceptible S. aureus bloodstream infection? Infect. Control Hosp. Epidemiol. 2009, 30, 453-460. [CrossRef] [PubMed]

9. Götz, F. Staphylococcus and biofilms. Mol. Microbiol. 2002, 43, 1367-1378. [CrossRef] [PubMed]

10. Abee, T.; Kovacs, A.T.; Kuipers, O.P.; van der Veen, S. Biofilm formation and dispersal in Gram-positive bacteria. Curr. Opin. Biotechnol. 2011, 22, 172-179. [CrossRef] [PubMed]

11. Costerton, J.W.; Lewandowski, Z.; Caldwell, D.E.; Korber, D.R.; Lappin-Scott, H.M. Microbial biofilms. Annu. Rev. Microbiol. 1995, 49, 711-745. [CrossRef] [PubMed]

12. Otto, M. Staphylococcal biofilms. Curr. Top. Microbiol. Immunol. 2008, 322, 207-228. [PubMed]

13. Brooks, J.D.; Flint, S.H. Biofilms in the food industry: Problems and potential solutions. Int. J. Food Sci. Technol. 2008, 43, 2163-2176. [CrossRef]

14. Gomes, F.; Saavedra, M.J.; Henriques, M. Bovine mastitis disease/pathogenicity: Evidence of the potential role of microbial biofilms. Pathog. Dis. 2016, 74, ftw006. [CrossRef] [PubMed]

15. Young, R. Bacteriophage lysis: Mechanism and regulation. Microbiol. Rev. 1992, 56, 430-481. [PubMed]

16. Loessner, M.J. Bacteriophage endolysins-Current state of research and applications. Curr. Opin. Microbiol. 2005, 8, 480-487. [CrossRef] [PubMed]

17. Fischetti, V.A. Bacteriophage lytic enzymes: Novel anti-infectives. Trends Microbiol. 2005, 13, $491-496$. [CrossRef] [PubMed]

18. Schmelcher, M.; Donovan, D.M.; Loessner, M.J. Bacteriophage endolysins as novel antimicrobials. Future Microbiol. 2012, 7, 1147-1171. [CrossRef] [PubMed]

19. Haddad Kashani, H.; Schmelcher, M.; Sabzalipoor, H.; Seyed Hosseini, E.; Moniri, R. Recombinant Endolysins as Potential Therapeutics against Antibiotic-Resistant Staphylococcus aureus: Current Status of Research and Novel Delivery Strategies. Clin. Microbiol. Rev. 2018, 31, 300071-17. [CrossRef] [PubMed]

20. Nelson, D.C.; Schmelcher, M.; Rodriguez-Rubio, L.; Klumpp, J.; Pritchard, D.G.; Dong, S.; Donovan, D.M. Endolysins as antimicrobials. Adv. Virus Res. 2012, 83, 299-365. [PubMed]

21. Schmelcher, M.; Shen, Y.; Nelson, D.C.; Eugster, M.R.; Eichenseher, F.; Hanke, D.C.; Loessner, M.J.; Dong, S.; Pritchard, D.G.; Lee, J.C.; et al. Evolutionarily distinct bacteriophage endolysins featuring conserved peptidoglycan cleavage sites protect mice from MRSA infection. J. Antimicrob. Chemother. 2015, 70, 1453-1465. [CrossRef] [PubMed]

22. O'Flaherty, S.; Coffey, A.; Meaney, W.; Fitzgerald, G.F.; Ross, R.P. The recombinant phage lysin LysK has a broad spectrum of lytic activity against clinically relevant staphylococci, including methicillin-resistant Staphylococcus aureus. J. Bacteriol. 2005, 187, 7161-7164. [CrossRef] [PubMed]

23. Gutierrez, D.; Ruas-Madiedo, P.; Martinez, B.; Rodriguez, A.; Garcia, P. Effective removal of staphylococcal biofilms by the endolysin LysH5. PLoS ONE 2014, 9, e107307. [CrossRef] [PubMed]

24. Jun, S.Y.; Jung, G.M.; Yoon, S.J.; Oh, M.D.; Choi, Y.J.; Lee, W.J.; Kong, J.C.; Seol, J.G.; Kang, S.H. Antibacterial properties of a pre-formulated recombinant phage endolysin, SAL-1. Int. J. Antimicrob. Agents 2013, 41, 156-161. [CrossRef] [PubMed]

25. Sass, P.; Bierbaum, G. Lytic activity of recombinant bacteriophage phi11 and phi12 endolysins on whole cells and biofilms of Staphylococcus aureus. Appl. Environ. Microbiol. 2007, 73, 347-352. [CrossRef] [PubMed]

26. Kaplan, J.B.; LoVetri, K.; Cardona, S.T.; Madhyastha, S.; Sadovskaya, I.; Jabbouri, S.; Izano, E.A. Recombinant human DNase I decreases biofilm and increases antimicrobial susceptibility in staphylococci. J. Antibiot. 2012, 65, 73-77. [CrossRef] [PubMed] 
27. Kaplan, J.B.; Ragunath, C.; Ramasubbu, N.; Fine, D.H. Detachment of Actinobacillus actinomycetemcomitans biofilm cells by an endogenous beta-hexosaminidase activity. J. Bacteriol. 2003, 185, 4693-4698. [CrossRef] [PubMed]

28. Kaplan, J.B.; Ragunath, C.; Velliyagounder, K.; Fine, D.H.; Ramasubbu, N. Enzymatic detachment of Staphylococcus epidermidis biofilms. Antimicrob. Agents Chemother. 2004, 48, 2633-2636. [CrossRef] [PubMed]

29. Gutierrez, D.; Briers, Y.; Rodriguez-Rubio, L.; Martinez, B.; Rodriguez, A.; Lavigne, R.; Garcia, P. Role of the Pre-neck Appendage Protein (Dpo7) from Phage vB_SepiS-phiIPLA7 as an Anti-biofilm Agent in Staphylococcal Species. Front. Microbiol. 2015, 6, 1315. [CrossRef] [PubMed]

30. Schmelcher, M.; Loessner, M.J. Bacteriophage endolysins: Applications for food safety. Curr. Opin. Biotechnol. 2016, 37, 76-87. [CrossRef] [PubMed]

31. Vanzieleghem, T.; Mahillon, J.; Jeanmart, H.; Degand, S.; Dupont, C.; Ladeuze, S. Fluidic Device for Studying of Surface-Dwelling Multicellular Layers and Microbial Biofilms. Eur. Pat. \# EP2706112, 12 March 2014.

32. Iordanescu, S.; Surdeanu, M. Two restriction and modification systems in Staphylococcus aureus NCTC8325. J. Gen. Microbiol. 1976, 96, 277-281. [CrossRef] [PubMed]

33. Novick, R.P.; Ross, H.F.; Projan, S.J.; Kornblum, J.; Kreiswirth, B.; Moghazeh, S. Synthesis of staphylococcal virulence factors is controlled by a regulatory RNA molecule. EMBO J. 1993, 12, 3967-3975. [PubMed]

34. Synnott, A.J.; Kuang, Y.; Kurimoto, M.; Yamamichi, K.; Iwano, H.; Tanji, Y. Isolation from sewage influent and characterization of novel Staphylococcus aureus bacteriophages with wide host ranges and potent lytic capabilities. Appl. Environ. Microbiol. 2009, 75, 4483-4490. [CrossRef] [PubMed]

35. Prasad, L.B.; Newbould, F.H. Inoculation of the bovine teat duct with Staph. aureus: The relationship of teat duct length, milk yield and milking rate to development of intramammary infection. Can. Vet. J. 1968, 9, 107-115. [PubMed]

36. Sambrook, J.; Fritsch, E.F.; Maniatis, T. Molecular Cloning: A Laboratory Manual; Cold Spring Harbor Laboratory: Cold Spring Harbor, NY, USA, 1989.

37. Verbree, C.T.; Dätwyler, S.M.; Meile, S.; Eichenseher, F.; Donovan, D.M.; Loessner, M.J.; Schmelcher, M. Corrected and Republished from: Identification of Peptidoglycan Hydrolase Constructs with Synergistic Staphylolytic Activity in Cow's Milk. Appl. Environ. Microbiol. 2018, 84, e02134-17. [CrossRef] [PubMed]

38. Schmelcher, M.; Loessner, M.J. Use of bacteriophage cell wall-binding proteins for rapid diagnostics of Listeria. Methods Mol. Biol. 2014, 1157, 141-156. [PubMed]

39. Vanzieleghem, T.; Couniot, N.; Herman-Bausier, P.; Flandre, D.; Dufrene, Y.F.; Mahillon, J. Role of Ionic Strength in Staphylococcal Cell Aggregation. Langmuir 2016, 32, 7277-7283. [CrossRef] [PubMed]

40. Jones, R.N.; Barry, A.L.; Gavan, T.L.; Washington Ii, J.A. Susceptibility tests: Microdilution and macrodilution broth procedures. In Manual of Clinical Microbiology; Balows, A., Hausler, J.W.J., Shadomy, H.J., Eds.; American Society for Microbiology: Washington, DC, USA, 1985; pp. 972-977.

41. Hall, M.J.; Middleton, R.F.; Westmacott, D. The fractional inhibitory concentration (FIC) index as a measure of synergy. J. Antimicrob. Chemother. 1983, 11, 427-433. [CrossRef] [PubMed]

42. Abramoff, M.D.; Magalhaes, P.J.; Ram, S.J. Image processing with Image. Biophotonics Int. 2004, 11, 36-43.

43. Cramton, S.E.; Gerke, C.; Schnell, N.F.; Nichols, W.W.; Götz, F. The intercellular adhesion (ica) locus is present in Staphylococcus aureus and is required for biofilm formation. Infect. Immun. 1999, 67, 5427-5433. [PubMed]

44. Boles, B.R.; Horswill, A.R. Agr-mediated dispersal of Staphylococcus aureus biofilms. PLoS Pathog. 2008, 4, e1000052. [CrossRef] [PubMed]

45. Schmelcher, M. ETH Zurich, Zurich, Switzerland. Removal of Staphylococcus aureus Biofilms from Abiotic Surfaces. 2014.

46. Montanaro, L.; Poggi, A.; Visai, L.; Ravaioli, S.; Campoccia, D.; Speziale, P.; Arciola, C.R. Extracellular DNA in biofilms. Int. J. Artif. Organs 2011, 34, 824-831. [CrossRef] [PubMed]

47. Zhang, Y.; Cheng, M.; Zhang, H.; Dai, J.; Guo, Z.; Li, X.; Ji, Y.; Cai, R.; Xi, H.; Wang, X.; et al. Antibacterial effects of phage lysin LysGH15 on planktonic cells and biofilms of diverse staphylococci. Appl. Environ. Microbiol. 2018. [CrossRef] [PubMed]

48. Melo, L.D.R.; Brandao, A.; Akturk, E.; Santos, S.B.; Azeredo, J. Characterization of a New Staphylococcus aureus Kayvirus Harboring a Lysin Active against Biofilms. Viruses 2018, 10, 182. [CrossRef] [PubMed]

49. Schuch, R.; Khan, B.K.; Raz, A.; Rotolo, J.A.; Wittekind, M. Bacteriophage Lysin CF-301, a Potent Antistaphylococcal Biofilm Agent. Antimicrob. Agents Chemother. 2017, 61, e02666-16. [CrossRef] [PubMed] 
50. Becker, S.C.; Roach, D.R.; Chauhan, V.S.; Shen, Y.; Foster-Frey, J.; Powell, A.M.; Bauchan, G.; Lease, R.A.; Mohammadi, H.; Harty, W.J.; et al. Triple-acting Lytic Enzyme Treatment of Drug-Resistant and Intracellular Staphylococcus aureus. Sci. Rep. 2016, 6, 25063. [CrossRef] [PubMed]

51. Drilling, A.J.; Cooksley, C.; Chan, C.; Wormald, P.J.; Vreugde, S. Fighting sinus-derived Staphylococcus aureus biofilms in vitro with a bacteriophage-derived muralytic enzyme. Int. Forum Allergy Rhinol. 2016, 6, 349-355. [CrossRef] [PubMed]

52. Chopra, S.; Harjai, K.; Chhibber, S. Potential of sequential treatment with minocycline and S. aureus specific phage lysin in eradication of MRSA biofilms: An in vitro study. Appl. Microbiol. Biotechnol. 2015, 99, 3201-3210. [CrossRef] [PubMed]

53. Fenton, M.; Keary, R.; McAuliffe, O.; Ross, R.P.; O’Mahony, J.; Coffey, A. Bacteriophage-Derived Peptidase CHAP(K) Eliminates and Prevents Staphylococcal Biofilms. Int. J. Microbiol. 2013, 2013, 625341. [CrossRef] [PubMed]

54. Fazekas, E.; Kandra, L.; Gyemant, G. Model for $\beta-1,6-N$-acetylglucosamine oligomer hydrolysis catalysed by DispersinB, a biofilm degrading enzyme. Carbohydr. Res. 2012, 363, 7-13. [CrossRef] [PubMed]

55. Ramasubbu, N.; Thomas, L.M.; Ragunath, C.; Kaplan, J.B. Structural analysis of dispersin B, a biofilm-releasing glycoside hydrolase from the periodontopathogen Actinobacillus actinomycetemcomitans. J. Mol. Biol. 2005, 349, 475-486. [CrossRef] [PubMed]

56. Mafu, A.A.; Plumety, C.; Deschenes, L.; Goulet, J. Adhesion of Pathogenic Bacteria to Food Contact Surfaces: Influence of $\mathrm{pH}$ of Culture. Int. J. Microbiol. 2011, 2011, 972494. [CrossRef] [PubMed]

57. Azeredo, J.; Azevedo, N.F.; Briandet, R.; Cerca, N.; Coenye, T.; Costa, A.R.; Desvaux, M.; Di Bonaventura, G.; Hébraud, M.; Jaglic, Z.; et al. Critical review on biofilm methods. Crit. Rev. Microbiol. 2017, 43, 313-351. [CrossRef] [PubMed]

58. Izano, E.A.; Amarante, M.A.; Kher, W.B.; Kaplan, J.B. Differential roles of poly- $N$-acetylglucosamine surface polysaccharide and extracellular DNA in Staphylococcus aureus and Staphylococcus epidermidis biofilms. Appl. Environ. Microbiol. 2008, 74, 470-476. [CrossRef] [PubMed]

59. O'Gara, J.P. ica and beyond: Biofilm mechanisms and regulation in Staphylococcus epidermidis and Staphylococcus aureus. FEMS Microbiol. Lett. 2007, 270, 179-188. [CrossRef] [PubMed]

60. Kropec, A.; Maira-Litran, T.; Jefferson, K.K.; Grout, M.; Cramton, S.E.; Götz, F.; Goldmann, D.A.; Pier, G.B. Poly-N-acetylglucosamine production in Staphylococcus aureus is essential for virulence in murine models of systemic infection. Infect. Immun. 2005, 73, 6868-6876. [CrossRef] [PubMed]

61. Waryah, C.B.; Wells, K.; Ulluwishewa, D.; Chen-Tan, N.; Gogoi-Tiwari, J.; Ravensdale, J.; Costantino, P.; Gokcen, A.; Vilcinskas, A.; Wiesner, J.; et al. In Vitro Antimicrobial Efficacy of Tobramycin Against Staphylococcus aureus Biofilms in Combination With or Without DNase I and/or Dispersin B: A Preliminary Investigation. Microb. Drug Resist. 2017, 23, 384-390. [CrossRef] [PubMed]

62. Elias, S.; Banin, E. Multi-species biofilms: Living with friendly neighbors. FEMS Microbiol. Rev. 2012, 36, 990-1004. [CrossRef] [PubMed]

63. Burmølle, M.; Ren, D.; Bjarnsholt, T.; Sørensen, S.J. Interactions in multispecies biofilms: Do they actually matter? Trends Microbiol. 2014, 22, 84-91. [CrossRef] [PubMed]

64. Djurkovic, S.; Loeffler, J.M.; Fischetti, V.A. Synergistic killing of Streptococcus pneumoniae with the bacteriophage lytic enzyme Cpl-1 and penicillin or gentamicin depends on the level of penicillin resistance. Antimicrob. Agents Chemother. 2005, 49, 1225-1228. [CrossRef] [PubMed]

(C) 2018 by the authors. Licensee MDPI, Basel, Switzerland. This article is an open access article distributed under the terms and conditions of the Creative Commons Attribution (CC BY) license (http://creativecommons.org/licenses/by/4.0/). 